\title{
GERMANY'S MILITARY IMPORTANCE FOR THE EUROPEAN UNION
}

\author{
Marius PRICOPI \\ "Nicolae Bălcescu" Land Forces Academy, Sibiu, Romania \\ pricopimarius@yahoo.com
}

\begin{abstract}
Although a founding member of the European Union, Germany has been rather reluctant to assume a pre-eminent leadership role in the European military integration process, choosing to focus more on social and economic affairs. But following Brexit, Germany might be also called upon to act as an integration "engine" in the defence area. Using the case study method and the analysis of social documents, we argue that Germany's high level of military integration allows this state to assume, alongside France, a leading role in the defence pursuits of the European Union.
\end{abstract}

\section{Keywords: European defence, the European Union, Germany, military integration}

\section{Introduction}

Given its recent past, Germany manifested a certain moderation in influencing the major European defence affairs. But nevertheless, Germany remains the most populated European Union (EU) country (with the fourth biggest territory), as well as the largest economy in the European space. Therefore, following Brexit, is it possible for Germany to assume (alongside France) the defence leadership role held by the United Kingdom (UK) in the EU? In the following, we argue that the answer to this question is a positive one.

\section{Methodology}

In writing the paper, we used the case study method as scientific tools, as it has been described in a comprehensive book authored by Robert Yin [1], as well as the analysis of social documents, as presented in a scientific work written by Glenn Bowen [2].

\section{Historical steps regarding Germany's military integration in the $\mathbf{E U}$}

Ever since the end of the Second World War and the beginnings of the European construction, the Federal Republic of Germany (FRG) had a consistent contribution to the process of European military integration.

To start with, on October 23, 1954 FRG joined the Brussels Treaty Organisation, which thus became the Western European Union.

A second major German contribution during the Cold War materialised in the Franco-German Brigade: a bi-national deployable military unit, which became operational in October 1989.

Following the end of the Cold War and Germany's reunification, the country renewed its efforts to enhance the common European defence structures. Hence, no later than October 1991, France and Germany initialized the setup of the first European military corps, on the foundation of the already established Franco-German Brigade; as participation in the military structure was open to all the Western European Union countries, Belgium decided to join the initiative, thus making possible the official launch of Eurocorps on October 1, 1993. Eurocorps was commanded by the German lieutenant- 
general Helmut Willman and was to represent the hard, military component of the Western European Union.

Finally, another historical landmark in Germany's involvement in the process of European military integration took place in 2004, through the establishment of the European Union's Battlegroups (alongside France and the United Kingdom) [3].

\section{Present-day German contributions to} the process of European military integration
Nowadays, Germany maintains a significant and steady contribution to the European defence affairs.

For starters, according to the annual Military Balance (2018), Germany has the second highest number of active military personnel in the EU, totalling 178,600 troops (Figure 1). Germany is surpassed by France and is closely followed by Italy; the other two EU members with high numbers of military men and women are Greece, respectively Spain.

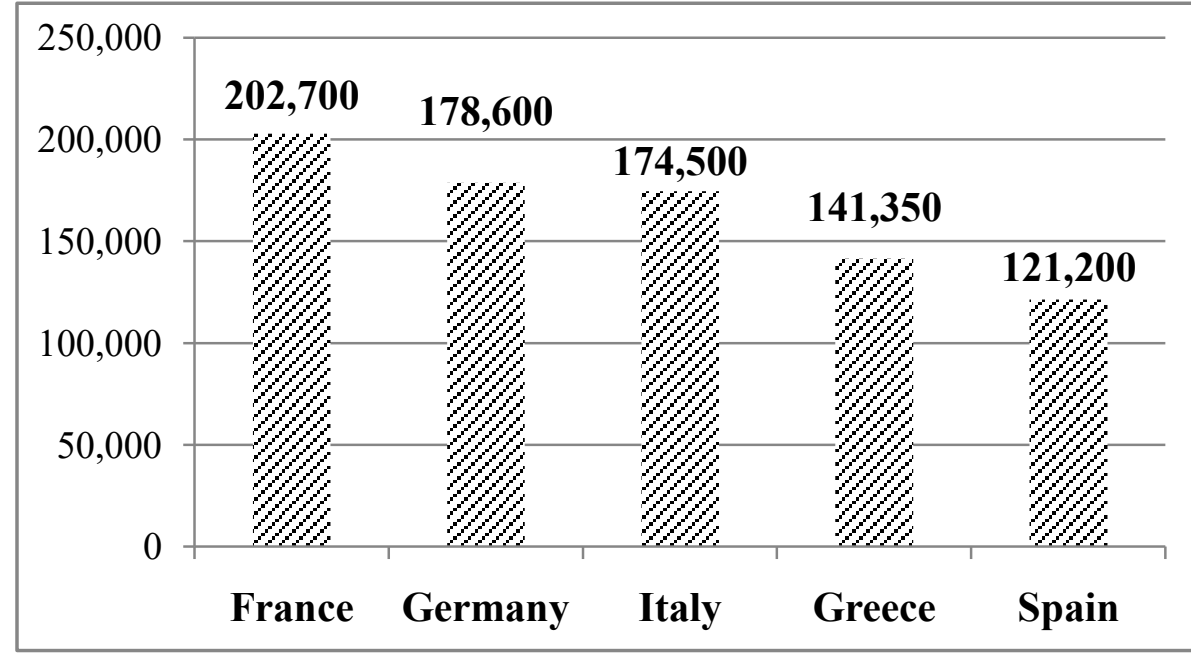

Figure 1: Top 5 EU Member States (excluding the UK) by Number of Active Military Personnel [4]

According to the same Military Balance, Germany covers no less than $16.20 \%$ of the total European defence spending (Figure 2). In this regard, the country is exceeded by only one other EU state: France, which accounts for $18.90 \%$ of the defence spending. Again, Italy follows Germany, but not as close as in the category of active military personnel, as Italy's percentage is almost twice as less as Germany's percentage.
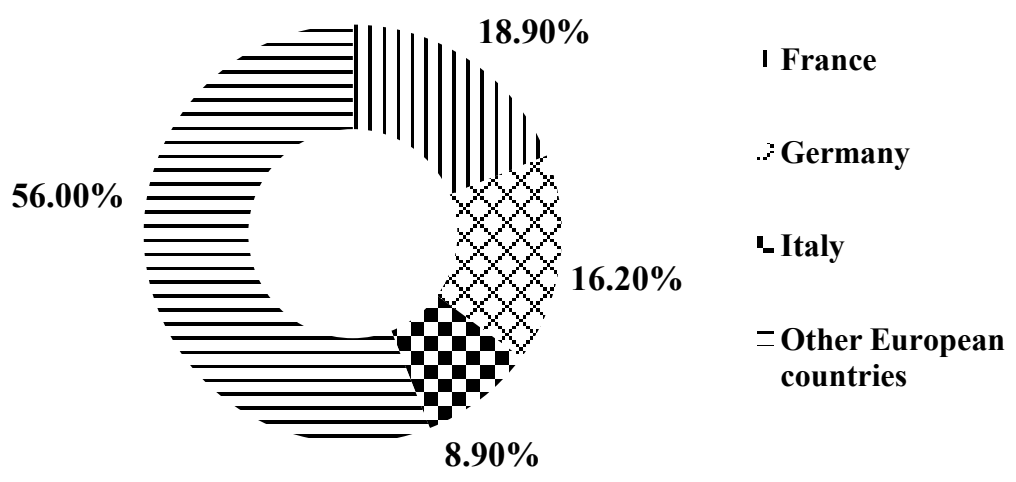

countries

Figure 2: Top 3 EU Countries (excluding the UK) by Defence Spending [5] 
Another argument for Germany to join France in leading the military integration process concerns the German defence industry. According to Table 1, Germany has no less than 4 presences in the SIPRI Top 100 Arms-Producing and Military Services Companies.

Table 1: EU Member States (excluding the UK) by Number of Companies in the SIPRI Top 100 [6]

\begin{tabular}{|c|c|c|}
\hline State & Number of Companies & Names of Companies \\
\hline \multirow{6}{*}{ France } & \multirow{6}{*}{6} & Thales \\
\hline & & Naval Group \\
\hline & & Safran \\
\hline & & $C E A$ \\
\hline & & Dassault Aviation Groupe \\
\hline & & Nexter \\
\hline \multirow{4}{*}{ Germany } & \multirow{4}{*}{4} & Rheinmetall \\
\hline & & ThyssenKrupp \\
\hline & & Krauss-Maffei Wegmann \\
\hline & & Hensoldt \\
\hline \multirow{2}{*}{ Italy } & \multirow{2}{*}{2} & Leonardo \\
\hline & & Fincantieri \\
\hline Poland & 1 & $P G Z$ \\
\hline Spain & 1 & Navantia \\
\hline
\end{tabular}

Some of these German companies are prestigious and very acknowledged within the European defence complex, and have implemented successful modernization contracts in many EU member states.
Moreover, the German companies present in SIPRI Top 100 had an increase in the percentage of arms sales in 2017, the year for which the latest date are available (Figure 3).

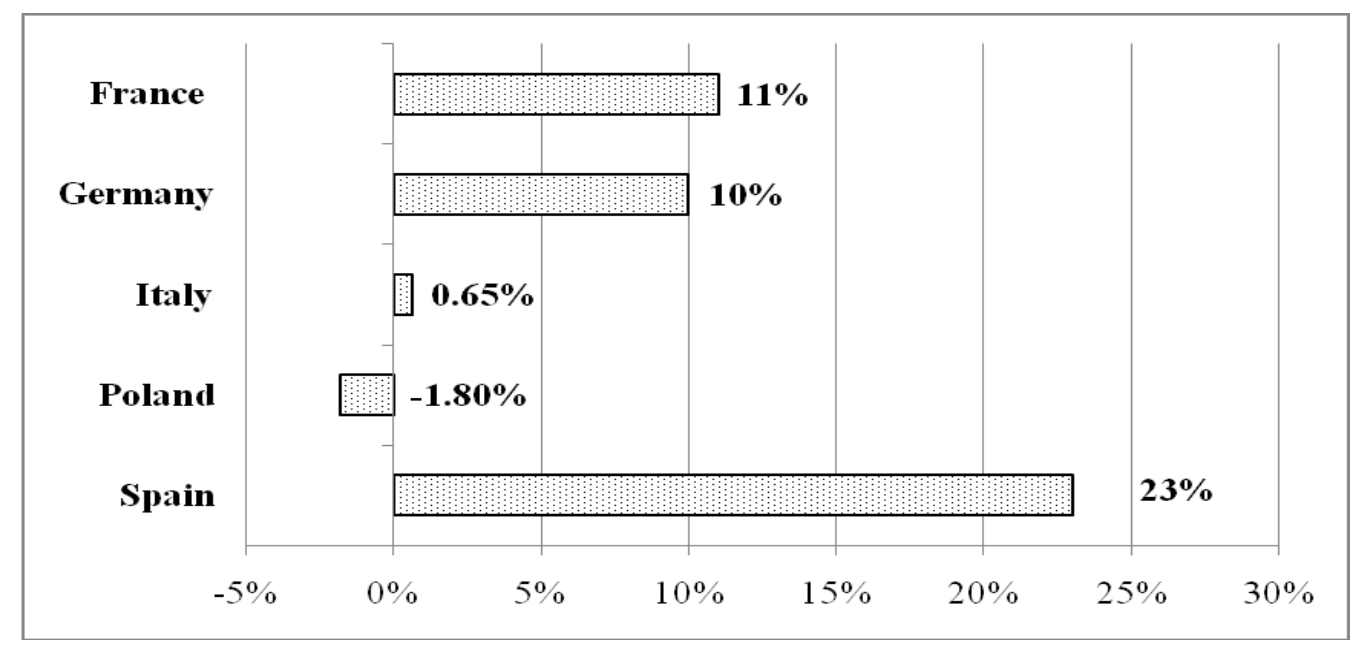

Figure 3: Percentage change in arms sales of EU companies (excluding the ones from the UK) in SIPRI Top 100 [7]

As one can observe, the biggest change was recorded by the Spanish company Navantia. France and Germany hold considerable positive changes of $11 \%$, respectively $10 \%$, whereas the two Italian companies (Leonardo and Fincantieri) 
averaged a modest increase of $0.65 \%$; on the other hand, the only negative change was recorded by the Polish company PGZ. Finally, another significant German contribution to the process of European military integration consists in the multinationalization of an EU operation Headquarters, located in the city of Ulm. Through such Headquarters (that are only present in three other EU countries: France, Greece and Italy), the Union holds both the premises and the technical infrastructure for fully planning and conducting autonomous military operations.

\section{Conclusions}

Since the end of the Second World War, the German state has had a constant and significant contribution to the process of European military integration. In this regard, one can recall that in 1954 the Federal Republic of Germany joined the Brussels Treaty Organisation (which subsequently transformed itself in the Western European Union), or that a later reunified Germany laid the foundations for the setup of Eurocorps and the EU Battlegroups.

Following Brexit - and also given the fact that the military dimension of security rebecomes more and more relevant [8] Germany might be appealed to partner with France in leading the process of European military integration. But is Germany ready to take on such an important role?

As we have presented, Germany has the highest performing economy and the highest number of citizens. Also, among the EU countries (excluding the UK), Germany has the second highest number of active military personnel and covers the second highest percentage of the total European defence spending. Moreover, Germany has no less than four companies present in the SIPRI Top 100 - companies that, according to the latest data, had an increase of $10 \%$ in their arms sales.

For all these arguments, the answer to the previous question would be a purposeful and assertive positive one.

\section{References}

[1] Robert Yin, Case Study Research: Design and Methods, Sage Publications, 2014.

[2] Glenn Bowen, Document Analysis as a Qualitative Research Method, Qualitative Research Journal, vol. 9, issue 2, 2009, pp. 27-40.

[3] Marius Pricopi, Integrarea militară europeană, Sibiu, Techno Media, 2014.

[4] International Institute for Strategic Studies, The Military Balance - 2018, Routledge, 2018, pp. 102, respectively 108, 118, 111 and 148 .

[5] International Institute for Strategic Studies, The Military Balance - 2018, Routledge, 2018 , p. 70.

[6] Stockholm International Peace Research Institute, The SIPRI Top 100 Arms-Producing and Military Services Companies (2017), SIPRI Factsheet, 2018, https://www.sipri.org/sites/default/files/2018-12/fs_arms_industry_2017_0.pdf, accessed on 12 March 2019.

[7] Stockholm International Peace Research Institute, The SIPRI Top 100 Arms-Producing and Military Services Companies (2017), SIPRI Factsheet, 2018, https://www.sipri.org/sites/default/files/2018-12/fs_arms_industry_2017_0.pdf, accessed on 12 March 2019.

[8] Ionuț Alin Cîrdei, A2AD concept in the modern security environment, "The KnowledgeBased Organization. The $24^{\text {th }}$ International Conference", 14-16 June 2018, Conference Proceedings 1: Management and Military Sciences, Land Forces Academy Publishing House, Sibiu, 2018, p. 50. 